\title{
CHARACTERIZATION OF DYE INDUSTRY EFFLUENT AND ASSESSMENT OF ITS SUITABILITY FOR IRRIGATION PURPOSE
}

\author{
Y. N. JOLLY AND A. ISLAM* \\ Chemistry Division, Atomic Energy Centre, P.O. Box 164 \\ 4, Kazi Nazrul Islam Avenue, Ramna, Dhaka-1000, Bangladsh \\ email: ash_islam2004@yahoo.com \\ AND \\ A. I. MUSTAFA \\ Department of Applied Chemistry and Chemical Technology \\ University of Dhaka, Dhaka-1000, Bangladesh. \\ Email:shafkat@agni.com
}

\begin{abstract}
A study was carried out to characterize dye industry effluent by measuring its various physicochemical characteristics and trace heavy metals and to asses its quality to be used as an alternate means of irrigation. As a case study the results obtained from the investigation of effluent of the Bangladesh Dyeing and Finishing Industries Ltd., Karnapara, Savar are reported in this study. The direct effluent (untreated effluent) and after it was treated in the laboratory (treated effluent) were investigated. As groundwater is a part of the effluent, it was also analysed. The average $\mathrm{pH}$ values of the untreated and treated effluents were found to be 7.83 and 5.13, respectively. The EC values of the untreated effluent $\left(1.81 \mathrm{mS} \mathrm{cm}^{-1}\right)$ and treated effluent $(2.01 \mathrm{mS}$ $\left.\mathrm{cm}^{-1} 1\right)$ were found to be higher than that of groundwater $\left(0.93 \mathrm{mS} \mathrm{cm}{ }^{-1}\right)$. No significant variation in $\mathrm{pH}$ and EC values of monthly collected effluent samples was observed. The average concentrations of trace elements except Fe were found to be lower than their DoE recommended values for irrigation land. The concentrations of $\mathrm{Na}$ and $\mathrm{K}$ in the untreated effluent were found to be higher and the $\mathrm{Ca}$ and $\mathrm{Mg}$ concentrations lower than those of the treated effluents. Assessment of the untreated and treated effluent was made based on their EC, the sodium adsorption ratio (SAR) and soluble sodium percent (SSP), COD and heavy trace metal contents. From the overall assessment, the treated effluent was found to be suitable for irrigation.
\end{abstract}

\section{INTRODUCTION}

Water pollution by industrial effluent has been one of the vital issues of the environmental concern in Bangladesh. The effluents from almost all industries of the country are directly or indirectly discharged into canals and rivers. Due to continuous disposal of wastewater into water bodies, the surface water quality throughout the country is getting gradually deteriorated because of the mixing of various chemical pollutants of the effluent with water. The surface water is an enormously used natural resource of Bangladesh. If the water pollution thus continues, the surface water quality will decline to such a level at which it will not be usable for any purpose.

Under this situation, it has become urgent to think of an alternate way of reducing the industrial impact on the environment and maintaining the water quality. The use of industrial liquid effluent for agricultural irrigation has been in vogue in many countries of the world $^{\mathbf{1 - 2}}$. This effluent contains various micronutrients essential for the growth of crop plants. Through simple treatment of industrial wastewater it can be used as an additional means of irrigation water of crop plants. As the micronutrient contents of the

\footnotetext{
* Corresponding author
} 
industrial effluent is higher than those of natural water ${ }^{3}$, the effluent can supply greater input of minerals for the better growth of crop plants. In addition, the use of industrial effluent for agricultural irrigation purpose can reduce the water pollution and dependency on agricultural use of groundwater. It needs to be mentioned that the groundwater level of the country is going down gradually due to its large scale yearly extraction for crop production.

With the increasing of demand of textile products, both nationally and internationally a large number of textile mills have grown in Bangladesh. But most of the dyeing industries discharge their effluents into the environment after partial treatment or without any treatment. The present study was therefore undertaken to characterize the effluent from a dyeing industry of Bangladesh for investigation of its physicochemical characteristics and heavy trace metals before treatment and after laboratory treatment and to evaluate its suitability to be used as an alternative means of irrigation water.

\section{MATERIALS AND METHODS}

Collection of effluent: Bangladesh Dyeing and Finishing Industries Ltd. situated at Karnapara, Savar was selected for effluent sampling. The samples were collected monthly starting from February, 2006 to September, 2006. The fresh detergent-washed and acid-treated polyethylene bottles with good stoppers were used to contain the samples. The pipe through which the effluent was collected was allowed to pass the effluent several times before collection of the represented one. The sample was then acidified with pure $\mathrm{HNO}_{3}(5 \mathrm{ml}$ per litre) to minimize metal adsorption on the container walls as well as to retard chemical and biological changes. The samples for anion determination were not acidified. Groundwater used by the plant was also collected. The $\mathrm{pH}$ and $\mathrm{EC}$ of the samples were measured in the field before they were acidified. The samples were brought to the laboratory and preserved in a refrigerator until they were further processed.

\section{Method of chemical treatment for removal of effluent colour}

According to the requirements of the study, the samples were divided into two groups. One of the groups was treated to remove their colour using a chemical precipitation method in which hydrated lime in combination with $\mathrm{FeCl}_{3}$ was used for precipitating the color material from the effluent ${ }^{4}$. For treatment, $500 \mathrm{ml}$ of effluent was taken in a 1 litre Pyrex beaker. The $\mathrm{pH}$ of the sample was increased to around 11.0 through the addition of hydrated lime under constant stirring condition. Then the coagulant $\mathrm{FeCl}_{3}$ solution was added to the sample and stirred rapidly for 15 minutes to allow maximum contact. After settling, the colourless supernatant was filtered using Whatman 40 filter paper.

Methods of Analysis: Two analytical techniques- AAS and Total Reflection X-ray Fluorescence (TXRF) were used for major and trace heavy metal analysis in untreated and treated effluent and groundwater. pH and EC of the samples were measured using a Jenwey $3051 \mathrm{pH}$ meter and a Jenwey 4070 conductivity meter, respectively. Chemical oxygen demand (COD) and anions were measured by adopting methods published in the standard method of chemical analysis ${ }^{5}$. Nitrogen and phosphate were measured by the Kjeldhal and colourimetric methods, respectively ${ }^{5}$. 


\section{RESULT AND DISCUSSION}

The analytical results are shown in Tables 1-2. The average $\mathrm{pH}$ and $\mathrm{EC}$ values of untreated effluent were 7.83 and $1.81 \mathrm{mScm}^{-1}$ and those of treated effluent were 5.13 and $2.01 \mathrm{mScm}^{-1}$, respectively. Groundwater showed the $\mathrm{pH}$ and $\mathrm{EC}$ values of 6.79 and 0.93 $\mathrm{mScm}^{-1}$, respectively. The higher $\mathrm{EC}$ value of treated effluent might be due to the increase of ions because of the addition of $\mathrm{FeCl}_{3}$ and $\mathrm{CaO}$ during treatment, but lower $\mathrm{pH}$ values due to the increase of hydrogen concentration in the system. This reverse results of $\mathrm{pH}$ and $\mathrm{EC}$ obtained for treated effluent were confirmed through verification which was carried out by measuring $\mathrm{pH}$ and $\mathrm{EC}$ of deionized water without and with the addition of $\mathrm{FeCl}_{3}$ and lime in deionized water. The similar results were observed. No significant variation was observed in

Table. 1.

Concentrations of Elements and Anions in Untreated and Treated Effluent

\begin{tabular}{|c|c|c|c|c|c|c|c|c|c|}
\hline \multirow{2}{*}{$\begin{array}{l}\text { Sampling } \\
\text { Months }\end{array}$} & \multirow{2}{*}{$\begin{array}{l}\text { Sample } \\
\text { Types }\end{array}$} & \multicolumn{7}{|c|}{ Cation and Anion Concentration $\left(\mathrm{MeqL}^{-1}\right)$} & \multirow[b]{2}{*}{$\mathrm{N}(\%)$} \\
\hline & & $\mathrm{Na}$ & $\mathrm{K}$ & $\mathrm{Ca}$ & $\mathrm{Mg}$ & $\mathrm{PO}_{4}^{-3}$ & $\mathrm{Cl}^{-1}$ & $\mathrm{SO}_{4}^{-2}$ & \\
\hline \multirow[t]{2}{*}{ February } & Untreated & $3.93 \pm 0.3$ & $1.74 \pm 0.1$ & $3.14 \pm 0.2$ & $0.72 \pm 0.01$ & $0.0831 \pm 0.002$ & $2.23 \pm 0.04$ & $0.72 \pm 0.02$ & $2.1 \pm 0.03$ \\
\hline & Treated & $3.86 \pm 0.4$ & $1.14 \pm 0.1$ & $4.70 \pm 0.2$ & $0.84 \pm 0.01$ & $1.0797 \pm 0.001$ & $3.27 \pm 0.02$ & $0.73 \pm 0.013$ & $1.78 \pm 0.02$ \\
\hline \multirow[t]{2}{*}{ March } & Untreated & $3.89 \pm 0.2$ & $1.76 \pm 0.1$ & $3.15 \pm 0.3$ & $0.75 \pm 0.02$ & $0.0830 \pm 0.002$ & $2.15 \pm 0.04$ & $0.74 \pm 0.02$ & $2.3 \pm 0.04$ \\
\hline & Treated & $3.79 \pm 0.2$ & $1.16 \pm 0.1$ & $4.75 \pm 0.3$ & $0.86 \pm 0.01$ & $1.0864 \pm 0.003$ & $3.30 \pm 0.02$ & $0.73 \pm 0.013$ & $1.89 \pm 0.02$ \\
\hline \multirow[t]{2}{*}{ April } & Untreated & $3.96 \pm 0.3$ & $1.71 \pm 0.2$ & $3.13 \pm 0.2$ & $0.73 \pm 0.02$ & $0.0833 \pm 0.002$ & $2.20 \pm 0.04$ & $0.71 \pm 0.02$ & $1.97 \pm 0.02$ \\
\hline & Treated & $3.88 \pm 0.3$ & $1.12 \pm 0.1$ & $4.69 \pm 0.3$ & $0.85 \pm 0.01$ & $1.0814 \pm 0.003$ & $3.29 \pm 0.02$ & $0.71 \pm 0.013$ & $1.63 \pm 0.01$ \\
\hline \multirow[t]{2}{*}{ May } & Untreated & $3.95 \pm 0.4$ & $1.69 \pm 0.2$ & $3.12 \pm 0.2$ & $0.74 \pm 0.01$ & $0.0832 \pm 0.002$ & $2.15 \pm 0.04$ & $0.73 \pm 0.02$ & $2.21 \pm 0.03$ \\
\hline & Treated & $3.86 \pm 0.2$ & $1.11 \pm 0.2$ & $4.69 \pm 0.2$ & $0.85 \pm 0.02$ & $1.1207 \pm 0.003$ & $3.28 \pm 0.02$ & $0.71 \pm 0.013$ & $1.83 \pm 0.02$ \\
\hline \multirow[t]{2}{*}{ June } & Untreated & $3.91 \pm 0.2$ & $1.70 \pm 0.2$ & $3.16 \pm 0.2$ & $0.71 \pm 0.02$ & $0.0829 \pm 0.001$ & $2.21 \pm 0.04$ & $0.71 \pm 0.02$ & $2.2 \pm 0.02$ \\
\hline & Treated & $3.84 \pm 0.2$ & $1.11 \pm 0.1$ & $4.76 \pm 0.3$ & $0.83 \pm 0.01$ & $1.0956 \pm 0.003$ & $3.31 \pm 0.02$ & $0.71 \pm 0.013$ & $1.79 \pm 0.02$ \\
\hline \multirow[t]{2}{*}{ July } & Untreated & $3.88 \pm 0.3$ & $1.73 \pm 0.1$ & $3.11 \pm 0.2$ & $0.72 \pm 0.01$ & $0.0831 \pm 0.002$ & $2.19 \pm 0.04$ & $0.69 \pm 0.02$ & $1.98 \pm 0.02$ \\
\hline & Treated & $3.78 \pm 0.3$ & $1.12 \pm 0.2$ & $4.71 \pm 0.2$ & $0.84 \pm 0.02$ & $1.0941 \pm 0.002$ & $3.31 \pm 0.02$ & $0.70 \pm 0.013$ & $1.88 \pm 0.02$ \\
\hline \multirow[t]{2}{*}{ August } & Untreated & $3.91 \pm 0.2$ & $1.74 \pm 0.2$ & $3.14 \pm 0.1$ & $0.73 \pm 0.01$ & $0.0830 \pm 0.001$ & $2.23 \pm 0.04$ & $0.71 \pm 0.02$ & $1.95 \pm 0.03$ \\
\hline & Treated & $3.87 \pm 0.3$ & $1.13 \pm 0.1$ & $4.71 \pm 0.1$ & $0.86 \pm 0.02$ & $1.0891 \pm 0.003$ & $3.29 \pm 0.02$ & $0.72 \pm 0.013$ & $1.89 \pm 0.02$ \\
\hline \multirow[t]{3}{*}{ September } & Untreated & $3.89 \pm 0.3$ & $1.68 \pm 0.1$ & $3.16 \pm 0.1$ & $0.74 \pm 0.01$ & $0.0832 \pm 0.002$ & $2.25 \pm 0.04$ & $0.71 \pm 0.02$ & $2.13 \pm 0.03$ \\
\hline & Treated & $3.80 \pm 0.2$ & $1.10 \pm 0.1$ & $4.73 \pm 0.2$ & $0.85 \pm 002$ & $1.1023 \pm 0.003$ & $3.30 \pm 0.02$ & $0.74 \pm 0.013$ & $1.94 \pm 0.03$ \\
\hline & $\begin{array}{l}\text { Ground } \\
\text { water }\end{array}$ & $3.88 \pm 0.2$ & $0.13 \pm 0.02$ & $3.90 \pm 0.1$ & $7.35 \pm 0.22$ & $0.058 \pm 0.002$ & $6.31 \pm 0.59$ & $0.01 \pm 0.01$ & $0.079 \pm 0.002$ \\
\hline \multicolumn{10}{|c|}{ Trace Element Concentrations $(\mathrm{mg} / \mathrm{L})$} \\
\hline $\begin{array}{l}\text { Sampling } \\
\text { Months }\end{array}$ & $\begin{array}{c}\text { Sample } \\
\text { Types }\end{array}$ & $\mathrm{Cr}$ & $\mathrm{Mn}$ & $\mathrm{Fe}$ & $\mathrm{Ni}$ & $\mathrm{Cu}$ & $\mathrm{Zn}$ & $\mathrm{Rb}$ & $\mathrm{Sr}$ \\
\hline \multirow[t]{2}{*}{ February } & Untreated & $0.27 \pm 0.07$ & $0.23 \pm 0.06$ & $3.29 \pm 0.08$ & $0.42 \pm 0.05$ & $1.51 \pm 0.07$ & $1.62 \pm 0.06$ & $0.27 \pm 0.05$ & $1.46 \pm 0.08$ \\
\hline & Treated & $<4 \mathrm{ppb}$ & $0.05 \pm 0.01$ & $4.57 \pm 0.09$ & $0.24 \pm 0.03$ & $0.86 \pm 0.04$ & $0.69 \pm 0.04$ & $0.13 \pm 0.03$ & $0.78 \pm 0.05$ \\
\hline \multirow[t]{2}{*}{ March } & Untreated & $0.26 \pm 0.06$ & $0.24 \pm 0.06$ & $3.29 \pm 0.07$ & $0.42 \pm 0.05$ & $1.51 \pm 0.07$ & $1.62 \pm 0.06$ & $0.27 \pm 0.05$ & $1.46 \pm 0.08$ \\
\hline & Treated & $<4 \mathrm{ppb}$ & $0.05 \pm 0.01$ & $4.57 \pm 0.09$ & $0.25 \pm 0.03$ & $0.85 \pm 0.03$ & $0.68 \pm 0.04$ & $0.13 \pm 0.03$ & $0.77 \pm 0.04$ \\
\hline \multirow[t]{2}{*}{ April } & Untreated & $0.27 \pm 0.07$ & $0.24 \pm 0.06$ & $3.29 \pm 0.08$ & $0.42 \pm 0.05$ & $1.51 \pm 0.07$ & $1.62 \pm 0.06$ & $0.27 \pm 0.05$ & $1.46 \pm 0.08$ \\
\hline & Treated & $<4 \mathrm{ppb}$ & $0.05 \pm 0.01$ & $4.57 \pm 0.09$ & $0.24 \pm 0.03$ & $0.85 \pm 0.03$ & $0.69 \pm 0.03$ & $0.12 \pm 0.02$ & $0.78 \pm 0.04$ \\
\hline \multirow[t]{2}{*}{ May } & Untreated & $0.27 \pm 0.06$ & $0.24 \pm 0.06$ & $3.29 \pm 0.08$ & $0.42 \pm 0.05$ & $1.51 \pm 0.07$ & $1.62 \pm 0.06$ & $0.27 \pm 0.05$ & $1.46 \pm 0.08$ \\
\hline & Treated & $<4 \mathrm{ppb}$ & $0.05 \pm 0.01$ & $4.57 \pm 0.09$ & $0.24 \pm 0.02$ & $0.85 \pm 0.03$ & $0.69 \pm 0.03$ & $0.13 \pm 0.03$ & $0.78 \pm 0.05$ \\
\hline \multirow[t]{2}{*}{ June } & Untreated & $0.26 \pm 0.06$ & $0.23 \pm 0.06$ & $3.29 \pm 0.08$ & $0.42 \pm 0.04$ & $1.51 \pm 0.08$ & $1.62 \pm 0.06$ & $0.27 \pm 0.05$ & $1.46 \pm 0.08$ \\
\hline & Treated & $<4 \mathrm{ppb}$ & $0.05 \pm 0.01$ & $4.57 \pm 0.09$ & $0.24 \pm 0.03$ & $0.85 \pm 0.03$ & $0.69 \pm 0.03$ & $0.13 \pm 0.03$ & $0.78 \pm 0.05$ \\
\hline \multirow[t]{2}{*}{ July } & Untreated & $0.27 \pm 0.06$ & $0.27 \pm 0.06$ & $3.29 \pm 0.08$ & $0.42 \pm 0.04$ & $1.51 \pm 0.07$ & $1.62 \pm 0.06$ & $0.27 \pm 0.05$ & $1.46 \pm 0.08$ \\
\hline & Treated & $<4 \mathrm{ppb}$ & $0.05 \pm 0.01$ & $4.57 \pm 0.09$ & $0.25 \pm 0.02$ & $0.85 \pm 0.03$ & $0.69 \pm 0.04$ & $0.13 \pm 0.03$ & $0.78 \pm 0.05$ \\
\hline \multirow[t]{2}{*}{ August } & Untreated & $0.27 \pm 0.07$ & $0.27 \pm 0.07$ & $3.29 \pm 0.08$ & $0.42 \pm 0.05$ & $1.51 \pm 0.08$ & $1.62 \pm 0.06$ & $0.27 \pm 0.05$ & $1.45 \pm 0.08$ \\
\hline & Treated & $<4 \mathrm{ppb}$ & $0.05 \pm 0.01$ & $4.57 \pm 0.09$ & $0.24 \pm 0.03$ & $0.86 \pm 0.03$ & $0.69 \pm 0.04$ & $0.12 \pm 0.02$ & $0.77 \pm 0.04$ \\
\hline \multirow[t]{2}{*}{ September } & Untreated & $0.263 \pm 0.06$ & $0.24 \pm 0.06$ & $3.29 \pm 0.08$ & $0.42 \pm 0.05$ & $1.51 \pm 0.07$ & $1.62 \pm 0.06$ & $0.27 \pm 0.05$ & $1.45 \pm 0.08$ \\
\hline & Treated & $<4 \mathrm{ppb}$ & $0.05 \pm 0.01$ & $4.57 \pm 0.09$ & $0.24 \pm 0.02$ & $0.86 \pm 0.07$ & $0.69 \pm 0.04$ & $0.13 \pm 0.03$ & $0.77 \pm 0.04$ \\
\hline \multicolumn{2}{|c|}{ Ground water } & $<4 \mathrm{ppb}$ & 0.002 & 0.003 & $<5 \mathrm{ppb}$ & 0.002 & $<3 \mathrm{ppb}$ & $<4 \mathrm{ppb}$ & $<4.6 \mathrm{ppb}$ \\
\hline
\end{tabular}

the $\mathrm{pH}$ and EC values of monthly collected effluent samples. The average COD value of untreated effluent was $180.73 \mathrm{mg} \mathrm{L}^{-1}$. For raw sedimented or filtered sewage water the ratio of $\mathrm{BOD}_{5}: \mathrm{COD}^{6}$ ranges from about 0.44 to 0.55 . Taking the $\mathrm{BOD}_{5}: \mathrm{COD}=0.5$ 
the $\mathrm{BOD}_{5}$ of present effluent was found to be $90 \mathrm{mg} \mathrm{L}^{-1}$. As biological treatment is not recommended for wastewaters with $\mathrm{BOD}_{5}$ ranging from 50 to $100 \mathrm{mg} \mathrm{L}^{-1}$ the present effluent did not need any biological treatment for use ${ }^{6}$. The mean concentrations of $\mathrm{Na}$ and $\mathrm{K}$ were found to be higher and the mean concentrations of $\mathrm{Ca}$ and $\mathrm{Mg}$ were lower than those of the

Table. 2.

Physicochemical Characteristic levels of Untreated and Treated Dye Industry Effluent

\begin{tabular}{|c|c|c|c|c|c|c|}
\hline $\begin{array}{l}\text { Sampling } \\
\text { Months }\end{array}$ & $\begin{array}{c}\text { Sample } \\
\text { Types }\end{array}$ & pH & 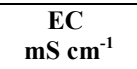 & COD, mg L$^{-}$ & $\begin{array}{c}\text { Dissolved Solid } \\
(\%)\end{array}$ & $\begin{array}{c}\text { Total Solid } \\
(\%)\end{array}$ \\
\hline \multirow[t]{2}{*}{ February } & Untreated & $7.84 \pm 0.6$ & $1.80 \pm 0.02$ & $178.79 \pm 0.14$ & $0.12815 \pm 0.0004$ & $0.1385 \pm 0.0006$ \\
\hline & Treated & $5.19 \pm 0.03$ & $1.99 \pm 00.2$ & - & - & - \\
\hline \multirow[t]{2}{*}{ March } & Untreated & $7.79 \pm 0.5$ & $1.77 \pm 0.01$ & $185.28 \pm 0.15$ & $0.12761 \pm 0.0004$ & $0.1392 \pm 0.0006$ \\
\hline & Treated & $5.21 \pm 0.05$ & $1.91 \pm 00.2$ & - & - & - \\
\hline \multirow[t]{2}{*}{ April } & Untreated & $7.90 \pm 0.6$ & $1.82 \pm 0.01$ & $174.95 \pm 0.14$ & $0.12797 \pm 0.0004$ & $0.13884 \pm 0.0006$ \\
\hline & Treated & $5.22 \pm 0.05$ & $2.03 \pm 0.02$ & - & - & - \\
\hline \multirow[t]{2}{*}{ May } & Untreated & $7.87 \pm 0.6$ & $1.81 \pm 0.01$ & $182.37 \pm 0.14$ & $0.12843 \pm 0.0004$ & $0.13895 \pm 0.0006$ \\
\hline & Treated & $4.98 \pm 0.04$ & $2.04 \pm 0.01$ & - & - & - \\
\hline \multirow{2}{*}{ June } & Untreated & $7.88 \pm 0.7$ & $1.81 \pm 0.02$ & $184.91 \pm 0.15$ & $0.1254 \pm 0.0004$ & $0.1391 \pm 0.0006$ \\
\hline & Treated & $5.17 \pm 0.03$ & $1.99 \pm 0.01$ & - & - & - \\
\hline \multirow{2}{*}{ July } & Untreated & $7.59 \pm 0.5$ & $1.79 \pm 0.02$ & $179.58 \pm 0.14$ & $0.1287 \pm 0.0004$ & $0.13871 \pm 0.0006$ \\
\hline & Treated & $5.18 \pm 0.03$ & $1.98 \pm 0.02$ & - & - & - \\
\hline \multirow[t]{2}{*}{ August } & Untreated & $7.91 \pm 0.5$ & $1.84 \pm 0.02$ & $182.67 \pm 0.15$ & $0.12789 \pm 0.0004$ & $0.13896 \pm 0.0006$ \\
\hline & Treated & $5.11 \pm 0.03$ & $2.01 \pm 0.02$ & - & - & - \\
\hline \multirow[t]{2}{*}{ September } & Untreated & $7.84 \pm 0.4$ & $1.81 \pm 0.01$ & $177.32 \pm 0.13$ & $0.12799 \pm 0.0004$ & $0.1391 \pm 0.0006$ \\
\hline & Treated & $4.99 \pm 0.04$ & $2.02 \pm 0.02$ & - & - & - \\
\hline \multicolumn{2}{|c|}{ Ground water } & $6.79 \pm 0.4$ & $0.93 \pm 0.001$ & $10.80 \pm 0.05$ & $0.143 \pm 0.002$ & $0.159 \pm 0.002$ \\
\hline
\end{tabular}

corresponding treated samples. The higher concentrations of $\mathrm{Ca}$ in the treated effluent samples was due to the addition of lime for treatment. The presence of $\mathrm{Mg}$ in lime as impurities might be responsible for its higher value in the treated samples. It was observed that the concentrations of anions in untreated effluents $\left(\mathrm{PO}_{4}{ }^{-3}: 0.083, \mathrm{Cl}^{-1}\right.$ : 2.20, $\left.\mathrm{SO}_{4}^{-2}: 0.71 \mathrm{Meq} / \mathrm{L}\right)$ were found to increase after treatment where the respective anion concentrations were 1.09, 3.29, $0.72 \mathrm{Meq} / \mathrm{L}$. ((Table.1). The average contents of $\mathrm{N}$ and $\mathrm{PO}_{4}^{-3}$ in untreated effluent were $2.10 \%$ and $0.083 \mathrm{Meq} \mathrm{L}^{-1}$ and in treated effluent were $1.82 \%$ and $1.09 \mathrm{Meq} \mathrm{L}^{-1}$, respectively. The DoE recommended values of $\mathrm{Cl}^{-1}$ and $\mathrm{N}$ are $2.20 \mathrm{Meq} / \mathrm{L}$ and $0.01 \%(\mathrm{v} / \mathrm{v})$, respectively. The concentration of $\mathrm{PO}_{4}^{-3}, \mathrm{Cl}^{-1}$ and $\mathrm{SO}_{4}^{-2}$ can be several tenths of $\mathrm{mg} \mathrm{L}^{-1}$, tens to hundreds of $\mathrm{mg} \mathrm{L}^{-1}$ and units to tens of $\mathrm{mg}$ $\mathrm{L}^{-1}$ in surface waters, respectively ${ }^{7}$. The groundwater contents of $\mathrm{N}$ and $\mathrm{PO}_{4}^{-3}$ were much lower than those of untreated and treated effluents. The average concentrations of trace elements except Fe (Mn: 0.05, Ni: 0.24, Cu: 0.85, $\mathrm{Zn}: 0.69 \mathrm{mg} \mathrm{L}^{-1}$ ) in treated effluent were lower than the DoE recommended values (Cr: 1, Mn: 5, Ni: 1, Cu: 3, Zn: $10 \mathrm{mg} \mathrm{L}^{-1}$ ) for industrial effluent suitable for discharge into irrigation land ${ }^{8}$. The toxic element levels were found below their detection limit $\left(\mathrm{Pb}:<10 \mu \mathrm{g} \mathrm{L}^{-1}, \mathrm{Cd}:<3 \mu \mathrm{g} \mathrm{L}^{-1}\right)$.

According to US Department of Agriculture ${ }^{9}$ the quality of untreated and treated dye effluent was classified for irrigation purpose based on electrical conductivity (EC) 
and sodium adsorption ratio (SAR) diagram (Fig.1) where SAR is calculated by using the equation-1:

By putting the mean EC and SAR values for untreated (EC: $1.81 \mathrm{mS} \mathrm{cm}^{-1}$; SAR: 2.82) $S A R=\frac{\left(\mathrm{Na}^{+}\right)}{\sqrt{\frac{\left(\mathrm{Ca}^{2+}\right)+\left(\mathrm{Mg}^{2+}\right)}{2}}}$ where all ions are exp ressed in MeqL ${ }^{-1}$

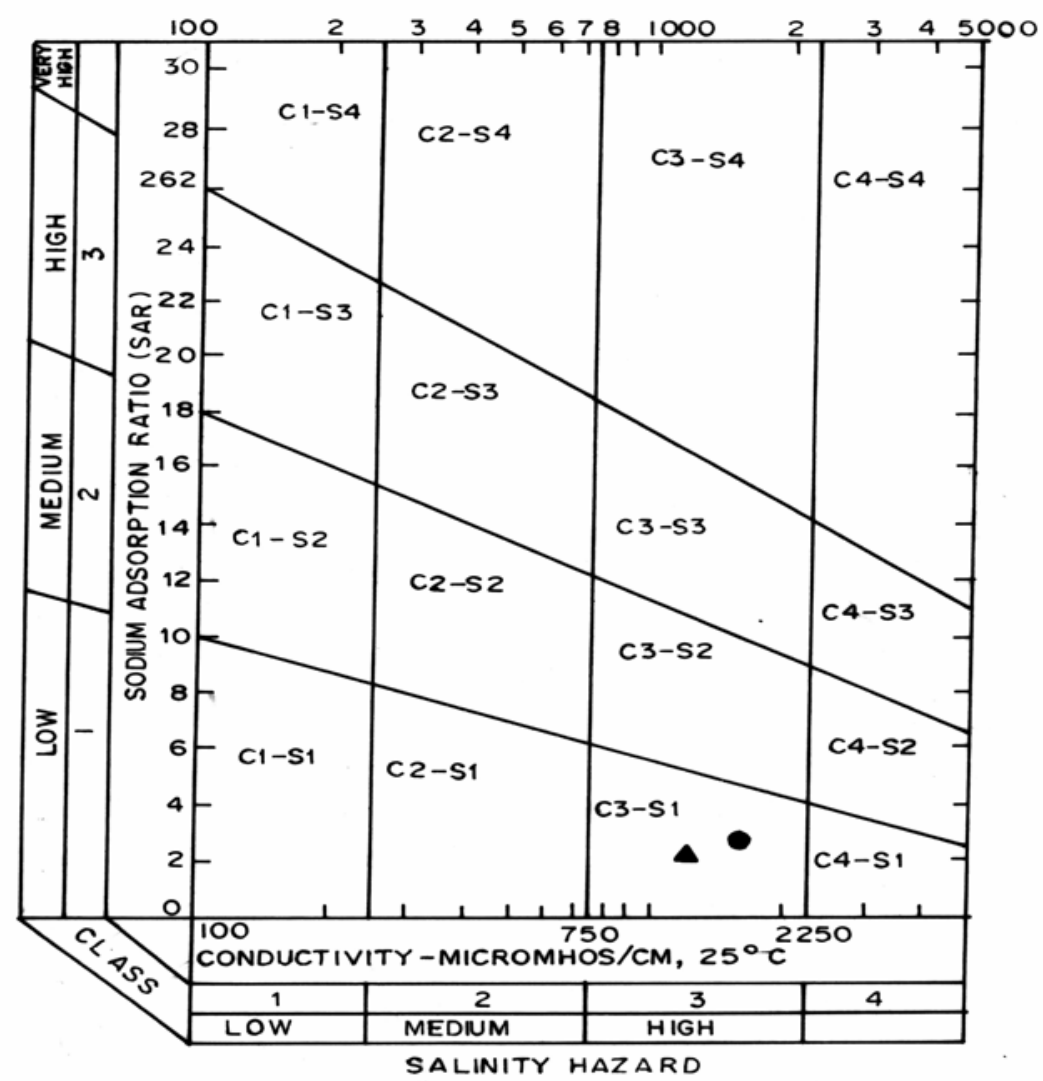

Fig. 1. Evaluation of Dye Factory Effluents for irrigation purposes according to us Department of Agricultur (1969) - untreated effluent $\Delta$ treated effluent.

and treated effluent (EC: $1.20 \mathrm{mS} \mathrm{cm}^{-1}$; SAR: 2.30) it was found that both the effluent types fell into the $\mathrm{C}_{3}-\mathrm{S}_{1}$ relating to water of high salinity and low sodium content and marginal for human consumption. The similar salinity of untreated and treated effluent was due to closeness between their total dissolved salts contents. However, in Bangladesh salinity is not normally a threat where there is salt free rain water for crop production $^{10}$. The qualities of both untreated and untreated effluent have also been 
assessed using Wilcox's diagram (Fig. 2) constructed based on EC value and soluble sodium percentage (SSP) which can be calculated by the following equation- $2^{9,10}$.

$S S P=\frac{\mathrm{Na}^{+}+\mathrm{K}^{+}}{\mathrm{Ca}^{2+}+\mathrm{Mg}^{2+}+\mathrm{Na}^{+}+\mathrm{K}^{+}} \times 100 \quad$ where allions are $\exp$ ressed in $\mathrm{MeqL}^{-1}$

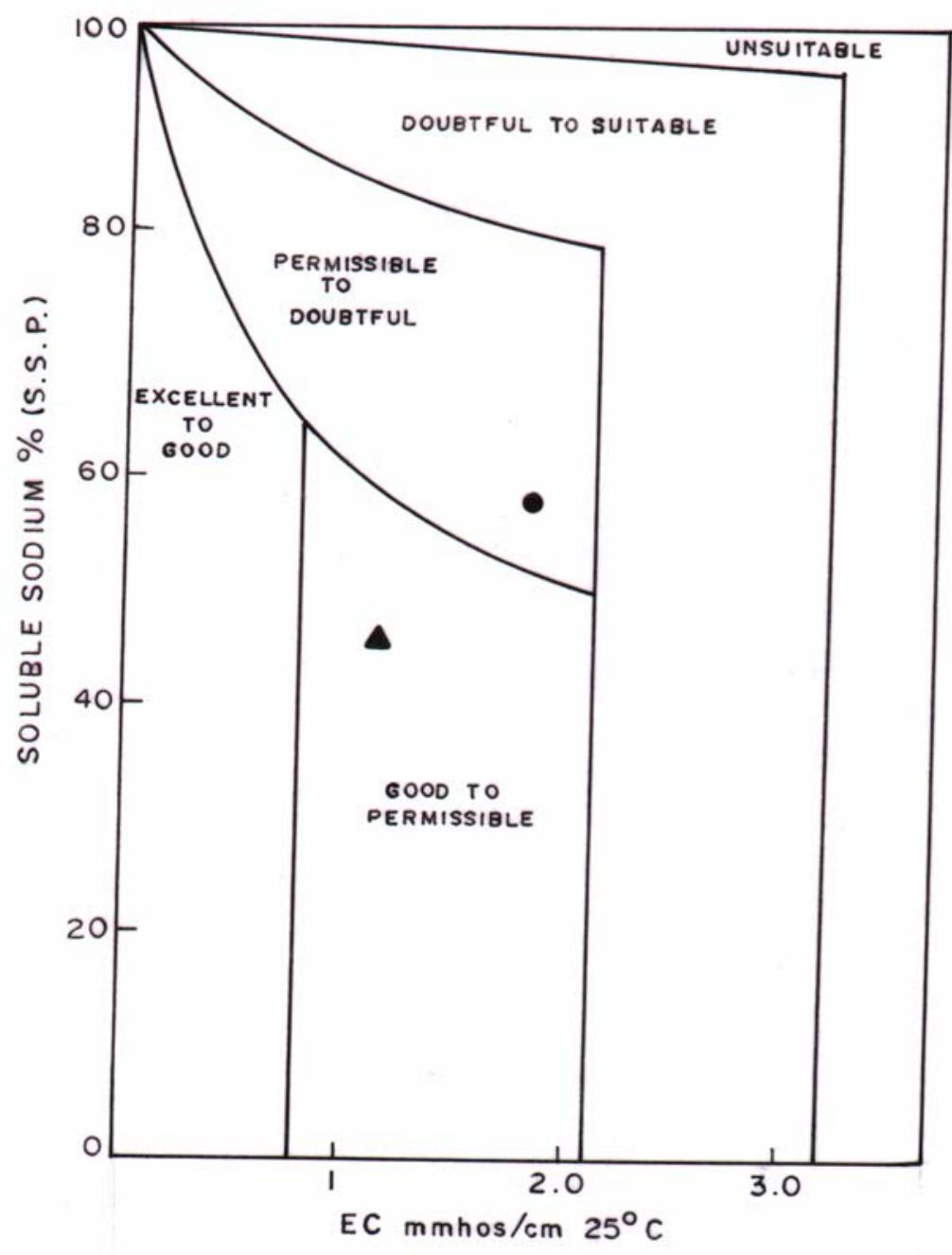

Fig. 2. Evaluation of Dye Factory Effluentfor irrigation purposes according to wilcox's diagram. Untreated effluent

$\Delta$ Treated effluent. 
By putting the average EC and SSP for untreated (EC: $1.81 \mathrm{mScm}^{-1}$; SSP: 59.29) and treated effluent (EC: $1.20 \mathrm{mScm}^{-1}$; SSP: 47.12) into Wilcox's diagram, two points, one for untreated effluent and another for treated effluent were obtained. The point for untreated effluent corresponds to the class 'permissible to doubtful' but in the case of treated effluent the point corresponds to the class 'good to permissible' for irrigation purposes (Fig. 2).

\section{CONCLUSION}

The suitability of effluent discharged from the Bangladesh Dyeing and Finishing Industries Ltd., Savar has been studied based on its physicochemical properties and trace element contents for irrigation purpose. The collected effluent after its treatment in the laboratory was also similarly investigated. Though the salinity of both untreated and treated effluent were high, based on the justification of irrigation-suitability of both effluent through Wilcox's diagram test, the untreated effluent was found to be unsuitable and the treated effluent suitable for the irrigation purpose. Besides, the untreated effluent was considered unsuitable as it contained some coloured dyes which might have adverse effects on soil after its use as an irrigation means. Moreover, the trace element contents of untreated effluent were found to be about double of those of the treated effluents. On the other hand, the untreated effluent turned transparent after treatment. The concentrations of trace heavy metals in treated effluent have not exceeded the recommended values and the toxic element contents were below their detection limits in treated effluent. However, from the overall aspects of the study, the treated effluent was considered suitable as an alternate means of irrigation on the conditions of monitoring the long-term effect of the effluent on soils so that there is no buildup of salinity or heavy trace metals that may be harmful for the system.

\section{ACKNOWLEDGEMENT}

Authors are grateful to the Ministry of Science, Information and Communication Technology, Bangladesh, for financial grant and Bangladesh Dyeing and Finishing Industries Ltd., Savar Bangladesh for giving permission to collect effluent samples for the present investigation.

\section{REFERENCES}

1. K. K. SINGH AND L. C. MISHRA, Water Air and Soil pollut., 33, 309, 1987.

2. M. AJMAL, M. A. KHAN, AND A. A. NOMANI, Environ. Pollut., (Ser A) 33, 97, 1984.

3. Y. N. JOLLY, A.ISLAM, S. B. QURAISHI AND A. I. MUSTAFA, J. Banladesh Sci. and Appl., 32(1), 41, 2008.

4. A. ISLAM, Nuclear Sci. and Applications, 15(1), 28, 2006.

5. MICHAEL, J. T., "Water analysis. In: Standard Methods of Chemical Analysis (part B), F.J. WELCHER (ed), 2388-2439, $6^{\text {th }}$ edition, Robert E. Krieger Publishing Co. Inc., Huntington, New York, USA.

6. P. PITTER and J. PROUSEK, The Chemical Composition of Water. In: Chemistry and Biology of Water, Air and Soil; Environmental Aspects, J. Tolgyessy (ed.) pp. 223-231, $1^{\text {st }}$ edition, Elsevier Science Publishers, Amsterdam, the Netherlands. 
7. M. PIATRIK, Wastewaters. In: Chemistry and Biology of Water, Air and Soil; Environmental Aspects, J. Tolgyessy (ed.) pp. 84-91, $1^{\text {st }}$ edition, Elsevier Science Publishers, Amsterdam, the Netherlands.

8. Industrial Effluents Quality Criteria. In: A Compilation of Environmental Laws (Bangladesh Gazette Additional 28), M.E. Huq (ed), pp. 60-62, Department of Environment, The Ministry of Environment and Forests, Bangladesh.

9. Gleen J. Hoffman, Biological Systems Engineering, Water Quality for Irrigation, EC 782, pubs@unl.edu

10. D .K. TODD, Groundwater hydrology John Willy and Sons, Inc, New York, 1980. 